\title{
Visual humour on the Internet ${ }^{1}$
}

\author{
Anneli Baran
}

\begin{abstract}
This article focuses on the role of visual imagery in language understanding. It is commonly held that the use of phraseologisms is most characteristic to spoken language. However, today we are faced with a situation where the usage of written and oral language has blended (in e-mails, on-line communication, social network) on the Internet. Creative use of expressions, even if manifested in an exaggerated or inappropriate manner, may lead to interesting figures of speech. I am going to concentrate on a subgenre of Internet memes - demotivational posters or manipulated photos which contain figurative expressions. Clearly, it is the creative context of the Internet that has given a new life to figurative expressions. People are interpreting phraseologisms differently from a traditional vis-à-vis conversation when being engaged in spontaneous virtual communication. In addition, the iconic nature of the motivation involved in understanding figurative expressions makes it possible to use the phrases as a means of visualisation. That is why it is possible to confirm that phraseological units are remarkably more complex phenomena than simple reproducible linguistic units that do not contain metaphors.
\end{abstract}

Keywords: Internet, demotivators, visualisation, figurative expressions, humour

\section{Introduction}

Visualisation is a very efficient tool in getting a message (be it informative, entertaining, etc.) across. It is particularly true in the Internet era when an almost new language form, the Internet language, has developed (Crystal 2001: 19). Some of its features include the blending of written and oral language (which is a thoroughly studied feature of the medium), and the animation of

1 The article has been written with the support of state programmes SF0030181s08 Narrative Aspects of Folklore. Power, Personality and Globalization, EKKM09-150 Database of Estonian Phrases and Publication of Estonian Phraseology in the Series Monumenta Estoniae Antiquae. 
writing. On the Internet, both is equally important - what is presented and how is it done. I will concentrate on a phenomenon at the juncture of figurative thinking, visualisation, and humour found on the Estonian-language Internet - demotivators.

A great part of the Internet is made up of visual communication. However, this type of communication is understudied. On the one hand, low interest by researchers can be explained by the short life of net-related phenomena, and on the other hand, by a general tendency to regard computer-mediated as well as visual communication as profane because it mostly occurs in the mass media and culture (Laaniste 2005: 617). In addition to special language use and the modified nature of communication, content is created differently from the pre-computerised era.

Arising from the unique phenomenon of the Internet, a discussion about the Internet memes has been initiated. Memes themselves are information aggregations (ideas, habits, figures, etc.) that spread, multiply and mutate in the human culture environment. Leading advocates of this idea, Richard Dawkins and Susan Blackmore, have published some of the most remarkable works on this topic. Susan Blackmore has developed the meme theory furthest and emphasises that the meme is actually a parasite that cannot be destroyed or fought against (Blackmore 1999: 110-111).

Internet memes are memes distributed through the Internet. Or, more specifically - they are an expression of an idea spread in social networks, blogs, e-mails and other channels, occurring as a hyperlink, video, image, website, word/phrase or symbol (Wikipedia). ${ }^{3}$ Such memes may change or disappear over time, i.e. they can be a relatively short-term phenomena.

One remarkable example of memes is the phenomenon of demotivators. Initially, posters were used in schools and offices to motivate people - so-called motivational posters. These posters then occurred on the Internet mostly in a parody mode; this is why they are called demotivators. I will discuss the features of demotivators in more detail later.

2 The more elaborated statement originates from the interview Blackmore gave to an Estonian newspaper six years after her book "Meme machine" was published. There she explains her theory in the light of the newest developments of the Internet, and says that the meme is actually a parasite (Blackmore 2005).

3 The best introduction or overview of this topic is available on a website entitled KnowYourMeme - http://knowyourmeme.com/. 


\section{The role of visualisation in the understanding of figurative expressions}

The Internet as a communication environment has for a while interested me primarily from the perspective of how phraseology is contextualised, i.e. how the Internet users apply traditional expressions in their Internet communication. Imagery of sayings has been a frequent topic of studies and discussions. Studying the figurativeness and logic of proverbs and traditional sayings is a way to approach this issue. For example a blog called Vanasõnasõel ('Sieve of proverbs') discusses the visual imagery of proverbs.

The role of visuality in understanding language imagery is very well represented in theoretical literature. This branch of research was initiated by cognitive psycholinguists such as Raymond W. Gibbs Jr., Sam Glucksberg, Cristina Cacciari, Rachel Giora, and others.

What are the possible meanings of imagery, a term that has been used a great deal in phraseology? In German phraseology (Burger 2003) there are two terms, distinguishing Bildlichkeit or imagery and Bildhaftigkeit or imaginarity and visuality. ${ }^{5}$ Imagery must be understood here as a language quality that initiates a special imagination capacity (visualisation capacity). Thus, it is possible to imagine something visually. Certain words and expressions are associated with certain situations as they have a clear link to the reality. According to cognitive linguists such as R. W. Gibbs Jr., and based on the experiments of other psycholinguists, it has been maintained that the motivating experiments are psychologically valid because the results refer to the cognitive reality of motivation (Gibbs 2002: 457).

In the case of some idioms, words contained in the expressions and their direct meanings are so figurative that the whole event can be imagined as visual-concrete. Such figures are called quasi-visual by Dmitrij Dobrovolskij and Anatoli Baranov (2008: 112), i.e. the figures that may be, although not essentially are, related to the real actual meanings of the idioms. The mental activity related to the process of imagination may vary. People's imagery of phraseologisms allows individual experiences and thus these activities are not prescribed, but generate different interpretations. In some sense, the activity related to the interpretation may vary from person to person.

In recent years, researchers have struggled to explain the importance of mental figurations. For this purpose, many psychological tests have been car-

4 http://propverb.blogspot.com/

5 In Estonian (like in English), these terms can unfortunately be hardly distinguished: according to EKSS [Dictionary of Estonian Literary Language], the term piltlikkus ('figurativeness') means imagery and kujundlikkus ('figurativeness') designates the same. 


\section{Anneli Baran}

ried out among people who learn English as a second language. Although the assessment methodology is still being developed, the results clearly show that the interpretation of images is greatly individual. However, the results of the researches also demonstrate that the visualisation process particularly helps in processing the totally unknown idioms, doing it more effectively than a verbal explanation would (Boers et al. 2009). The latter may help with the interpretation but not necessarily. It is obvious that only understanding the words is not enough. Apart from the metaphors intending to be a universal model for the detection of central figures, understanding a language also assumes acknowledging the cultural context. In case this is missing, a phraseological understanding can be created by the visualisation of the image. However, as understanding is consciously controlled (or at least tries to be), the reception is greatly cognitive, i.e. construction of meanings is individual. As demonstrated by experiments, a full agreement is extremely exceptional (Szczepaniak \& Lew 2011).

Herewith I will give examples of how imagery works in phraseologisms or proverbs, visualising the content of expressions.

In some Internet websites for entertainment, like the one with a very characteristic name, Mängukoobas - ajaviiteurg ('Game cave - entertainment den') photomontages can be found that come without a textual content, but the image is often followed by well-known phraseological sayings like in this example, stating See on ideaalne kostü̈̈m. Sammud maskeraadi poole! Nü̈̈d saan ma aru miks öeldakse "Ta on hunt lambanahas" (This is an ideal costume. Go to a masquerade! Now I see why it is said: "He is a wolf in sheep's skin.") (Fig. 1).

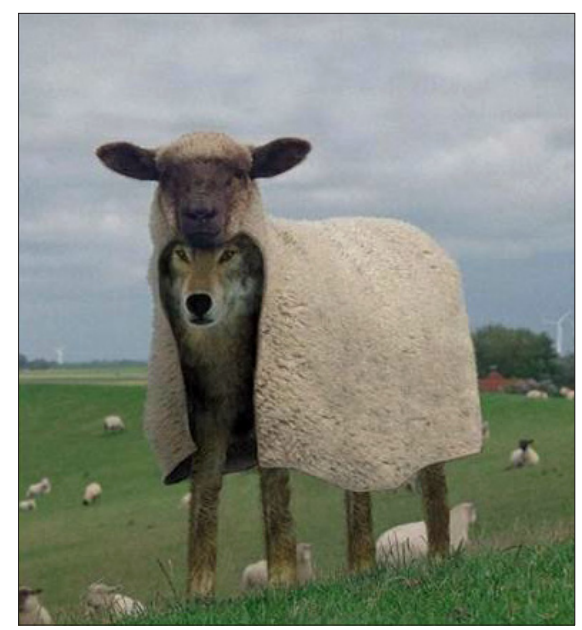

6 http://mangukoobas.lahendus.ee/
Figure 1. Photo image from the website Mängukoobas. http://mangukoobas.lahendus.ee/id/7/ action/full_media/media_id/289486/. 


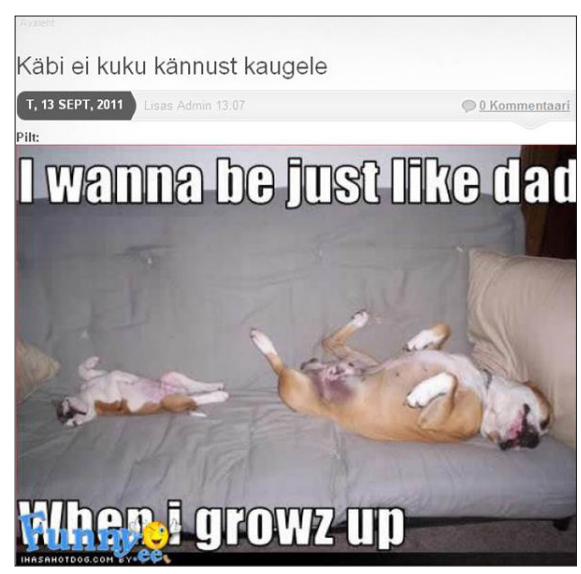

Figure 2. Photo image from the website Funny. ee. http://funny.ee/node/13.

This sort of photograph which has been digitally manipulated is a good example of the imagery and visualisation possibilities of phraseology. The comment under the image also expresses different understandings that people might have of the so-called actual meaning of a phraseological unit. It is obvious that the figurative meaning also contains the basis for visual imaginations that may help to understand the phraseologism, but on the other hand it may bring in additional elements that have nothing in common with the phraseological meaning of the phrase. ${ }^{7}$

Another example (Fig. 2) is titled using the traditional Estonian saying Käbi ei kuku kännust kaugele ('The acorn doesn't fall far from the tree'; in Estonian, "the pine cone") which clearly amplifies the caption below, written in English I want to be just like dad when I grow up. However, the visualisation here is not directly related to the literal meaning of the expression (pine-cone) bringing about figurative visualisation. Thesis of psycholinguists that the phraseological language units are subordinated to interpretation is thus confirmed.

\section{Demotivators as visual humour on the internet}

In this section I concentrate on demotivators, focusing on the cases which contain expressions as an impulse for visualisation.

\footnotetext{
7 In some ways it is similar to the resolution that follows incongruence known in humour theory (i.e. non-prototypic use) that creates a possibility for new marked interpretations and influences arising from them (Krikmann 2004: 130).
} 
As a rule, demotivators work through the contradiction between three elements $^{8}$ : more or less comic photos / photomontages (or manipulations), their titles (or slogans), and the captions (or so-called explanations / comments on the title) below them. The caption is specifically mock-philosophical or pedagogical. The result is often humorous, satirical and parodying. This sort of contradiction or incompatibility (cf. thesis versus antithesis) is in the very nature of demotivators, which means that the motivation present in true motivational posters is replaced by irony (that is why they have also been called "fake motivational posters").

Demotivators are particularly characterised by the lack of autonomy of the image as the image is always combined with a verbal message. Although in this case the image (photo/photomontage) would suffice, the content is still forwarded by the verbal part of the demotivator.

Demotivational posters are similar to poster art that was very common in the Soviet society and carried a motivating function (with slogans like "Honour work!" etc.). The political posters of the Soviet era are used nowadays on the Internet for creating photo collages or montages. The re-used Soviet slogans, illustrated in the vein of socialist realism, present images which function as constructs or conventional phenomena, detached from their their original use.

Demotivators can be defined as a subgenre of international Internet folklore or Internet humour (Vinnikov 2010). It is characteristic that they circulate in an anonymous Internet environment. ${ }^{9}$ Although those posters can occur almost everywhere on the Internet, including the online media (e.g. entertainment pages of news portals), they can be most often found in the form of systematised collections on special humour sites (so-called demotivators without demotiva$\left.\operatorname{tion}^{10}\right)$.

It is characteristic that such environments usually have thematic names in Estonian Internet: naerapooleks.com (literally, 'laugh one's head off.com'), vimka.delfi.ee ('prank.delfi.ee'), aegmaha.com ('timeout.com'), naljad.ee ('jokes. ee'), funny.ee, fail.ee (the latter with the subtitle "The funniest failures and successes"), hullumaja.com ('madhouse.com').

Such entertainment environments normally contain diverse materials like photos, videos and jokes. Among the photos there are snapshots of blunders and funny moments, but incidental demotivators (e.g. titled "Funny images") also form a frequent category.

8 The tripartite structure sometimes gets an addition from the fourth characteristic, the black frame that sets the background for a demotivator (see also Piekot 2012).

9 Similarly to demotivators, a slightly out-dated trend was to send humorous photomontages with captions (e.g. in Powerpoint format) to friends and colleagues by e-mail. These were titled with a general name (e.g. "Ideas", "Relax"). The purpose of these was entertainment.

${ }^{10}$ For the origin of the definition, see Russian research on demotivators (Golikov \& Kalashnikova 2010: 127). 
Categorisation principles seem to be the same in all of the abovementioned websites: jokes, funny pictures, and funny videos. For example, one site (naerapooleks.com) presents some distinguishable thematic categories, e.g. computers, animals, celebrities, people, sport, cars. A quick look at those sites shows us that jokes (in Estonian) are a dominant genre: fail.ee contains 676 "Estonian failures" and 1184 "foreign failures" (only images and videos); naljad.ee 346 images, 1122 jokes, 59 videos; vimka.delfi 478 photos, 27771 jokes, 116 videos (accessed in Aug 2011). As a rule, there is a possibility to comment and rate the uploaded images on the basis of the categories they are cast into, like "most recommended", "highly rated", "most commented", "the best", "the most popular", "the most favourite", "the coolest", and "hot". When new material is added, it is grouped as "new", "news", "recently added". There are topics with short names such as "other jokes / funny things", "miscellaneous", but also "this is cool", "this is scary", "awful". ${ }^{11}$ The most popular posters are usually available on the opening page.

Such environments are naturally represented in social network websites like Facebook and Twitter, which allows to share links the posters and and other items and to spread the most popular items.

It is clear that visual communication is more universal than verbal communication, effective across linguistic and cultural borders, and we can even say that the importance of language is almost non-existent in the contemporary world. However, belief in the universality of visuality is actually relative - this may vary by cultures. Understanding images is relative, depending on the cultural background. I will present two examples of demotivators from the website naerapooleks.com (Figs. 3) that represent local Estonian politicians and opinion leaders. Such jokes can be decoded and understood only by knowing the local circumstances, i.e. they are strongly intertextual in essence.

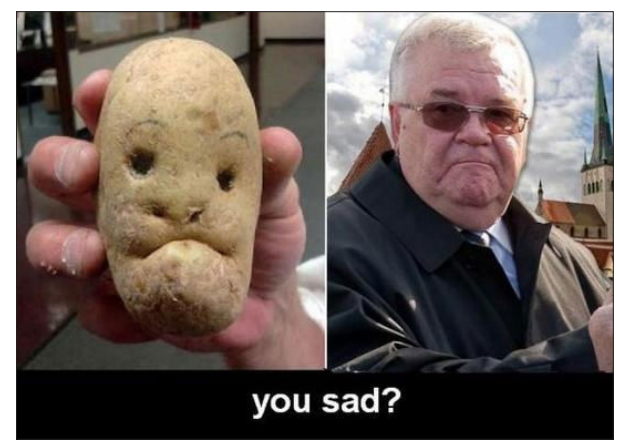

Figure 3.1. Mayor of Tallinn Edgar Savisaar - 'You sad?' http: / / naerapooleks.com/post/1088.

\footnotetext{
11 This aspect offers evidence against the claims of some Russian sociologists, who are of the opinion that demotivators allow but do not need the reactions of people (Golikov \& Kalashnikova 2010: 130).
} 


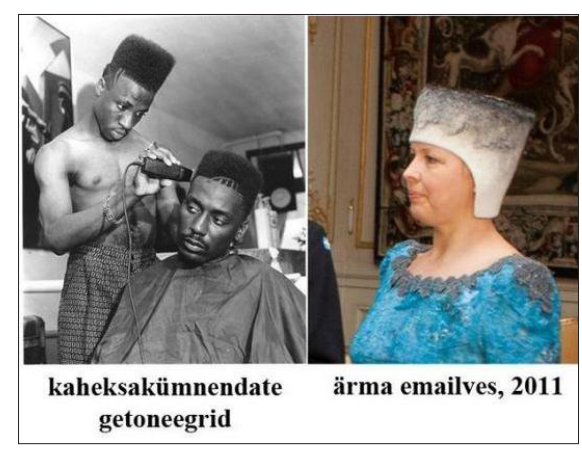

Figure 3.2. Estonian President's wifeMoodne kübar YO! Kaheksakümnendate getoneegrid ja Ärma emailves 2011.

Fashionable hat, yo! Chicness in the ghetto in the eighties and in Ärmafarmstead in 2011. http: / / naerapooleks. com/post/1071.

Some examples of distinctively Estonian material can be found on the abovementioned sites, but generally more international, translated material is featured there. The fixed structure of demotivators, in the strict sense, can be found there quite rarely. Thus, it can be expected that the Estonian phraseologisms or other traditional expressions are rarely used, as the majority of the material is of foreign origin. International jokes are widespread in Estonian, but in the case of visual humour, people are faithful to the original, and thus the original text in English (or Russian) is retained. An attempt to translate the text has been made in the case of some posters, so adaption to the local culture and language does occur, although minimally. Researchers Limor Shifman and Mike Thelwall have concluded in a similar vein that "the strong global aspect in the meme's diffusion is accompanied by a limited degree of glocalisation" (2009: 2576).

If we speak about Internet sites dedicated to demotivators, an Estonian site specialising in this genre existed until the end of 2011, titled demot.ee. Now the website has unfortunately closed down. The analysis presented in this study relies on the material drawn from the site in spring, summer and autumn 2011 and is thus a reflection of a stage rather than a full analysis of the phenomenon.

It was possible not just to view the uploaded posters, but also to add new posters on the website demot.ee. For this purpose, special software was available for download. There were also rules for users that prohibited the following actions (from the website http://demot.ee/old_publish.php):

- propagating organisations and movements;

- posting images that provoke only negative emotions or violate general ethical standards;

- posting materials with faulty spelling;

- using previously published posters and images.

In effect, these rules were flexible: the second requirement was quite freely interpreted and the third requirement on orthography was often ignored - at least in practice, as spelling mistakes were common. It is evident from the sample that a large amount of demotivational posters were of Russian origin and the Estonian adaptions included several orthographic mistakes. The section 
"The best" contained only a fraction of posters that used fragments of proverbs / sayings / slogans. As was mentioned before, a few demotivators were clearly of Estonian origin. Here I give some examples (Figs. 4) of demotivators containing Estonian proverbs and phrases ${ }^{12}$ :

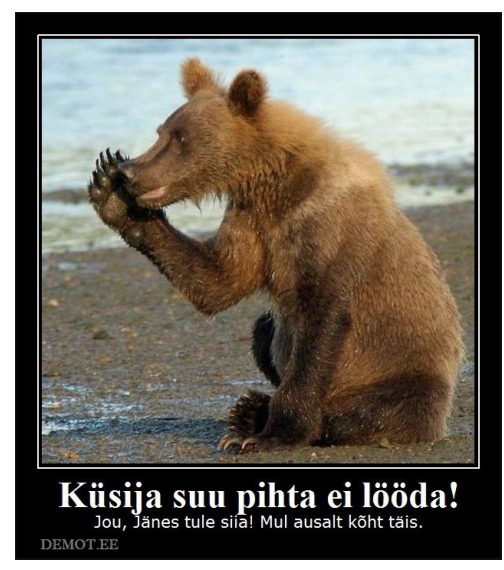

Figure 4.3. Küsija suu pihta ei lööda! > EV 5181 Küsija suu peale ei lööda. The one who asks will not beaten! www.demot.ee.

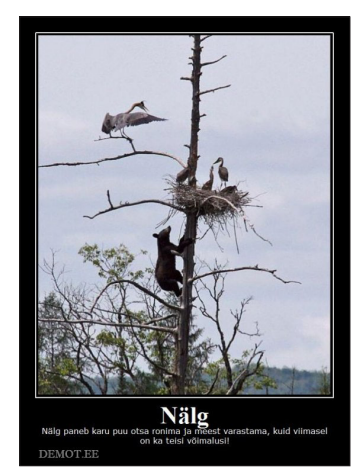

Figure 4.5. Nälg paneb karu puu otsa ronima ja meest varastama, kuid viimasel on ka teisi võimalusi. Hunger makes a bear climb up a tree and a man to steal, although the man has other possibilities. > EV 7707 Nälg sunnib karu käppa imema. 'Hunger makes a bear suck his paw.' EV 7679 Nälg ajab lapsed vargile. 'Hunger makes the children steal' www. demot.ee.

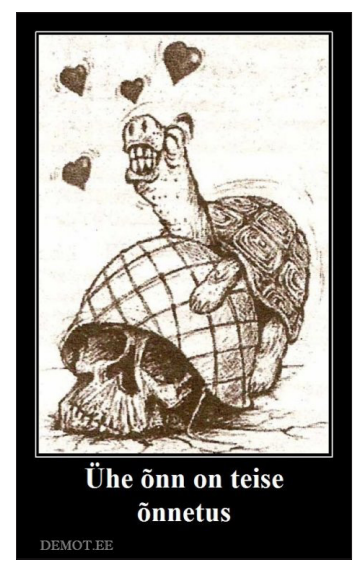

Figure 4.4. Ühe õnn on teise õnnetus. > EV 14733 Ühe õnn võib olla teise õnnetus. One's luck is bad luck for someone else. www.demot.ee.

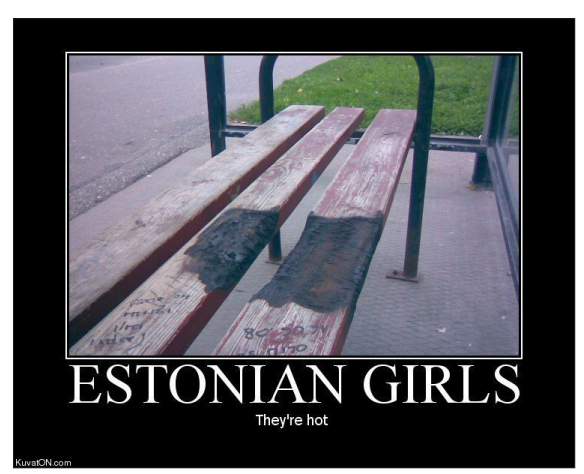

Figure 4.6. Estonian girls - they are hot! www.demot.ee.

12 The EV numbers indicate type numbers following the academic publication of "Estonian proverbs" ('Eesti vanasõnad'). 
These demotivators containing proverbs are great examples of creativity. In addition it can also be noticed that quite unknown proverbs can be used in demotivators (as the third example about the bear and hunger demonstrates).

The expression Estonian girls - they are hot! (see example [6]) can be related to a cycle of Russian jokes with "gorjachie estonskije parni", i.e. "hot Estonian boys" (conveying an ironic meaning of "very slow", as opposite to "hot-tempered" or "fiery") as main characters. Thus, it must have been actually a match that has been created on the basis of mutuality. In the quotation, this means just replacing one word.

In the next section I will take a closer look at one of the topics of Estonian demotivators: that of politics.

\section{Demotivators and other maniphotos ${ }^{13}$ about politicians on the Estonian Internet}

The aforementioned posters are naturally not limited to entertainment sites and social networks; they also occur in other Internet communities like forums or home pages. Visual humour can also be found in blogs. It is next to impossible to make groundbreaking generalisations on the basis of the present findings as it is complicated to have a complete overview of all the demotivators that exist on the Estonian Internet. In the following section, I will share some of my insights into the subject matter.

Coming back to the various possibilities that the Internet has to offer for visual communication, charismatic and legendary politicians dominate in this subsection, most notably, the aforementioned Mayor of Tallinn Edgar Savisaar, and the Prime Minister Andrus Ansip. As a rule, parodying is based on the temporary failure of these public figures: a faux-pas in a decision or uttering (see Figs. 5). It is popular to parody election advertising campaigns by reinterpreting their content. Campaigns contain political promises that provide material not just for funny quotes, but also for the development of visual humour. In particular, the objects of parody are above all the advertising posters and videos that undermine the electors. Thus, demotivational posters express a political viewpoint. Here parallels can be drawn between demotivators and the Soviet political poster culture. The difference is mainly the purpose - the Soviet poster was something quite different than entertainment. Such a parallel with the Soviet visual imagery rather refers to the developments of present day visual humour that can afford to be satirical and entertaining at the same

\footnotetext{
13 The term maniphoto is here used as a synonym of photomontage (see also Shifman
} 2007). 


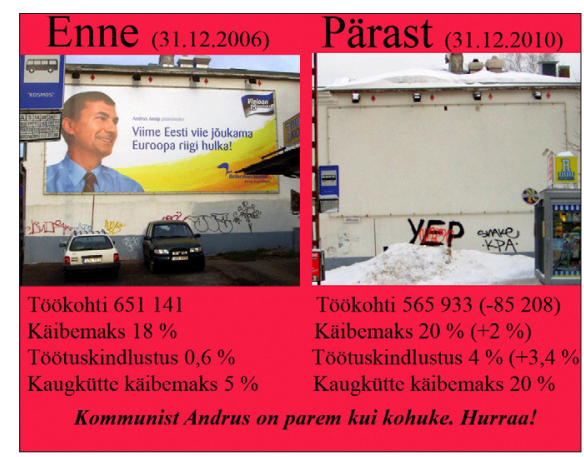

Figure 5.7. Enne ja pärast [valimisi]. Kommunist Andrus on parem kui kohuke. Hurraa! Before and after [elections]. Communist Andrus is better than cheese cake. Hurrah! http: / / virgokruve.wordpress.com/2011/08/08/euroopa-joukateriikide-edetabel-ehk-kellest-tuleb-mooduda-viie-rikkama-hulka-joudmiseks /.

time. Their sarcasm is pointed at the local heroes and anti-heroes. On the other hand, it also means that people's behaviour on the Internet is not restricted to entertainment only; on the contrary, they are socially and politically active in their contributions to forums, blogs, etc.

The Mayor of Tallinn is often depicted as having alleged political and economic orientation towards Russia (in addition to often accusing him of retaining the Soviet mentality), which is one of the most popular topics in the studied material. The same person, Edgar Savisaar, is often matched against the historical context when his actions are compared to those of the negative

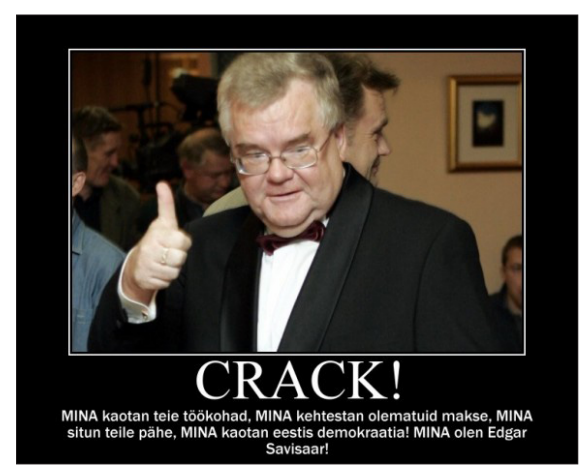

Figure 5.8. Crack! MINA kaotan teie töökohad, MINA kehtestan olematuid makse, MINA situn teile pähe. MINA kaotan eestis demokraatia! MINA olen Edgar Savisaar! Crack! I lost your jobs. I enforce non-existent taxes. I shit on you. I demolish the democracy in Estonia. I am Edgar Savisaar! http:/ / reg666.blogspot. com/2010/12/konspiraator.html.

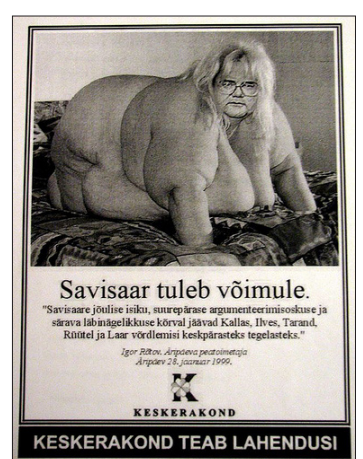

Figure 5.9. Savisaar tuleb võimule. Savisaare jõulise isiku, suurepärase argumenteerimisoskuse ja särava läbinägelikkuse kõrval jäävad Kallas, Ilves, Tarand, Rü̈̈tel ja Laar võrdlemisi keskpärasteks tegelasteks. Savisaar comes to power. [A selection of names of well known Estonian politicians] are dull in comparison to the powerful personality, argumentation skills and shrewdness of Savisaar. http:/ / voyag.blogspot.com/2006/05/ripev-savisaar-tuleb-vimule-ps.html. 


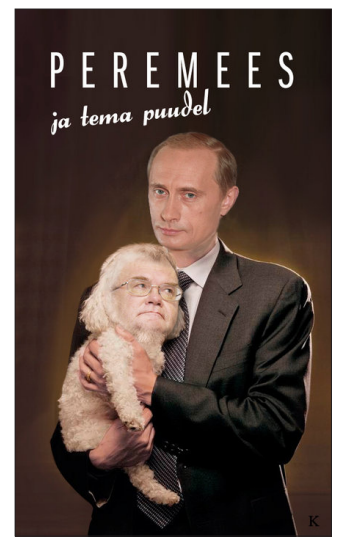

Figure 5.10. Peremees ja tema puudel. The Master and his Poodle. http:/ / usk-lootus-armastus.blogspot. com/2010/04/peremees-ja-tema-puudel.html.

leaders from the past (Stalin, Hitler), but also with the leader of present-day Russia (Putin) (see example [10]). Foreigners who are unfamiliar with the background can find these sorts of associations difficult to understand. L. Shifman, who has analysed Internet humour, claims that topics such as politics are prominently locally oriented (Shifman 2007: 199). These examples demonstrate again that traditionally the communicativeness of images is found to be more universal than verbal language, but at a closer look it is clear that the universal understanding works within the limits of cultural context (Laaniste 2005). An excellent understanding of a language does not guarantee the understanding of the images representing the use of language.

Texts that can be characterised as sayings are quite rare in the images ridiculing politicians. The captions are rather in the form of catch-phrases or quotes from the daily political discourse, e.g. slogans from elections (Crack! Centre Party knows the solutions!).

The other widespread source material that is used in creating demotivators or maniphotos are the images of the characters from significant and popular films that have gained the status of a pop culture symbol. In such cases, a portrait of a politician is used instead of a well-known film hero (from films

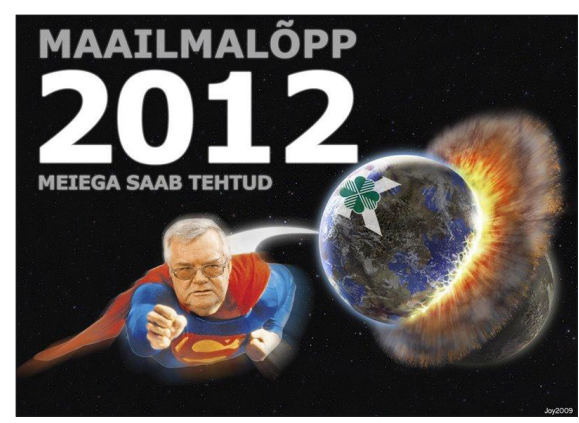

Figure 5.11. Maailmalõpp 2012. Meiega saab tehtud. End of the world 2012. It'll be done - with us. http: / / mangukoobas. lahendus.ee/id/7/action/full_media / media_id/270624/.

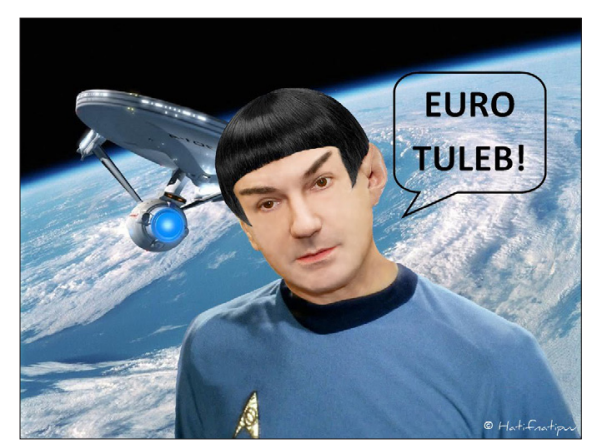

Figure 5.12. Euro tuleb! Euro must come! http: / / hatifnatipuu.blogspot. com/2010/07/avameelselt-eurost.html. 
"Terminator" and "Star Trek") (on the etymology of the catch-phrase "Done!", see the end of this section).

The use of such political characters is an evidence of their popularity, although this kind of attention is rather negative and critical. Although the popular political figures depicted in the Estonian material differ in their political views (right-wing (Ansip) versus center/left (Savisaar)), they are both guilty of populist declarations that give an incentive to ironise (not just by means of visual humour but also through jokes) (see example [13]).

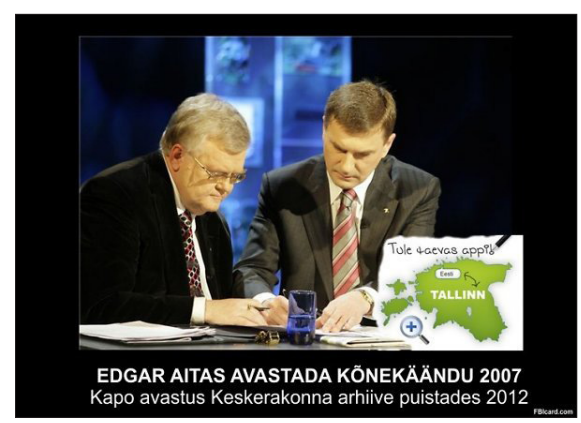

Figure 5.13. Edgar aitas avastada kõnekäändu [Tule taevas appi!] 2007. Kapo avastus Keskerakonna arhiive puistates 2012. Edgar helped to create the saying [Help us heaven!] 2007. Kapo [security police] discovered it when cleaning up the archives of the Estonian Centre Party in 2012. FBIcard.com.

To sum it up, we can state on the basis of the given examples that visual humour in Estonia, spreading in the form of Internet memes via demotivating posters or simple photomontages, is primarily designed as entertainment but also contains some political satire.

The same tendency is also demonstrated by another genre functioning as a channel for popular Internet memes. As mentioned above, the Internet offers different possibilities for visual (social) communication, and one kind of visual Internet humour are various multimedia phenomena, e.g. videos. The main source for Internet videos is dominantly YouTube, which has become a powerful website since 2005 when it was launched. It has become a widespread habit to share links to video clips in YouTube, for example via social networks. Thus, it is one form of social interaction.

One remarkable fact is that in the material of the school lore collection campaign among Estonian school children in 2007 (12 years after the previous collection of the youth lore), many popular sayings / catch phrases / slang and jokes were collected that are known in the sphere of Internet communication. In the campaign questionnaire on jokes, three familiar quotations were registered that originate from the local politicians and were made popular by video clips in YouTube, namely Tule taevas appi! ('Help us heaven!'), Ei kommentaari! ('No comment!'), and Tehtud! ('Done!'). Although these are short sentences and 
the last two are exceptionally laconic without any figurativeness, whereas the first one is traditional but by now obsolete (a rhetorical exclamation withdrawn from common use), these sentences have become popular because they have been popularised by a satirical show on a local television channel, Arapanija (lit. 'The one who puts away' or "Heckler"). These three sentences originate from different sources: the first from a government press conference (uttered by the Prime Minister Andrus Ansip), the second from a TV news programme (incorrect use of words / spelling by a Russian speaking politician Vladimir Beloi), and the third from an advertising campaign for elections (as a slogan of the party of the Mayor of Tallinn, Edgar Savisaar). Video clips from the satirical TV show were uploaded to YouTube, which made them go viral. Two of the three quotations - Tule taevas appi! and Tehtud! - are still used by both younger and older people without referring to the source; they have begun an independent life. Today, numerous hits can also be found in Google: the first quotation has 297,000 hits, the second 112,000, and the third 2,100,000. The reason for their popularity is in the context of their utterance: the authors of the sayings are well-known politicians to this day, although the author of the middle quote (Ei kommentaari) is above all known as the author of the utterance and not through his actions as a politician. The two other politicians were referred to in demotivators as well.

Even though the abovementioned quotes are very popular, it is still impossible to maintain that politicians remain a constant focus of interest for young people. Instead, the young generation tends to believe that the politicians insert funny or catchy quotes and utterances into their speech to consciously increase their popularity. Harald Burger has referred to the spontaneity of speech in television and radio programmes in his research about the mass media (1991: 50). He claims that politicians carefully weigh their words, but still have to be emotional, striking a balance between the two to achieve the highest influence. Regardless of whether their utterance is spontaneous or controlled, the result may be an expression that enters everyday discourse.

The abovementioned quotes represent the intertwining of visual humour and phraseology, although here the visualisation is vested in the distribution of the quotes via video clips. As noted in the introduction, we live in an era of visual influence and the visual sense is more utilised than any other senses. Thus, visual language has gained great importance. As a phraseologist I find that visualisation as a defining factor for the understanding of verbal language is only for our benefit. Moreover, appreciating the potential of figurative language will break down the entrenched stereotypes about the interaction between the verbal and visual realms. 


\section{Conclusion}

The visual side has never before dominated with such vitality as it does now when it gets support from the visuality of the Internet. This gives one more reason to study the phenomena of the visual language. How are they understood and does this kind of understanding vary considerably from the understanding of verbal language?

In the study of phraseology and figurative language use, the problems of the motivational aspect and consequent iconicity have been central to discussions. Arising from that, the phenomenon of demotivators, visual messages disseminated on the Internet, presents a great means for researching the underlying mechanisms of imagery. Besides, the role of cultural background elements is important not only in the identification of the figurative items, but also of the visual phenomena. Without doubt it is simpler to understand and analyse both verbal and visual humour that has begun to live its own life on the Internet, considering the associations it has in this context. Thus, it is obvious that even more attention should be paid to the so-called new type of contextualisation taking place in the virtual reality. It is possible to study why some messages in computer mediated communication become memes and others do not. And last but not least, it is worth researching if such phenomena are independent of different languages and cultures, or whether their universality remains superficial.

\section{References}

Baranov, Anatoli \& Dobrovolskij, Dmitrij 2008. = Баранов, А. Н., Добровольский, Д. О. 2008. Аспекты теории фразеологии. [Aspects of the theory of phraseology.] Российская академия наук, Институт русского языка им. В. В. Виноградова. Москва: Знак.

Blackmore, Susan 1999. The meme machine. Oxford: Oxford University Press.

Blackmore, Susan 2005. Inimest ei juhi jumal ega mõistus vaid müstiline meem. [Neither God nor intellect leads a human, but mystical meme.] Eesti Päevaleht. http://www.epl. ee/news/kultuur/article.php?id=51007268, last accessed on 23 January 2012.

Boers, Frank \& Piquer Píriz, Ana María \& Stengers, Hélène \& Eyckmans, June 2009. Does pictorial elucidation foster recollection of idioms? Language Teaching Research, Vol. 13, No. 4, pp. 367-382.

Burger, Harald 1991. Das Gespräch in den Massenmedien. Berlin; New York: de Gruyter.

Burger, Harald 2003. Phraseologie. Eine Einführung am Beispiel des Deutschen. Berlin: Erich Schmidt.

Crystal, David 2001. Language and the Internet. Cambridge: CUP.

EKSS = Eesti Keele Seletav Sõnaraamat. http://www.eki.ee/dict/ekss/, last accessed on 23 January 2012. 


\section{Anneli Baran}

EV = Eesti vanasõnad I-V (1980-1988). Monumenta Estoniae Antiquae III. Proverbia Estonica. A. Hussar \& A. Krikmann \& E. Normann \& V. Pino \& I. Sarv \& R. Saukas (com.), A. Krikmann \& I. Sarv (eds.) Tallinn: Eesti Raamat.

Gibbs, Raymond W. Jr. 2002. A new look at literal meaning in understanding what is said and implicated. Journal of Pragmatics, Vol. 34, No. 4, pp. 457-486.

Golikov \& Kalashnikova 2010 = Голиков, Александр Сергеевич \& Калашникова, Алина Александровна 2010. Демотиваторы в Интернет-коммуникации: генезис, смысл, типология. [Demotivators in Internet-communication: Generology, meaning, typology.] Вестник Харьковского государственного университета, pp. 124-130.

Krikmann, Arvo 2004. Koestler, Raskin, Attardo ja teised: Lingvistiliste huumoriteooriate uuemaist arenguist. [Koestler, Raskin, Attardo and others: On newest developments of linguistic humour theories.] Reetor 4. Tartu: Eesti Kirjandusmuuseumi folkloristika osakond, Eesti Kultuuriloo ja Folkloristika Keskus.

Laaniste, Mari 2005. Piltide ja kirja keelest. [On the language of pictures and writing.] Keel ja Kirjandus 8, pp. 617-629.

Shifman, Limor 2007. Humor in the age of digital reproduction. International Journal of Communication 1, pp. 187-209.

Shifman, Limor \& Thelwall, Mike 2009. Assessing global diffusion with web memetics: The spread and evolution of a popular joke. Journal of the American Society for Information Science and Technology, Vol. 60, No. 12, pp. 2567-2576.

Szczepaniak, Renata \& Lew, Robert 2011. The role of imagery in dictionaries of idioms. Applied Linguistics, Vol. 32, No. 3, pp. 323-347.

Vinnikov 2010 = Винников, Владимир 2010. Демотиваторы. Жанр русского фольклора. [Demotivators. A genre of Russian folklore.] http://zavtra.ru/cgi//veil//data/ zavtra/10/886/81.html, last accessed on 13 May 2012.

Wikipedia. http://en.wikipedia.org/wiki/Motivational_poster, last accessed on 23 January 2012.

\section{Internet sources}

http://demot.ee/, last accessed on 12 September 2011.

http://fbicard.com/, last accessed on 23 January 2012.

http://funny.ee/, last accessed on 23 January 2012.

http://hatifnatipuu.blogspot.com, last accessed on 23 January 2012.

http://mangukoobas.lahendus.ee, last accessed on 23 January 2012.

http://naerapooleks.com, last accessed on 23 January 2012.

http://propverb.blogspot.com/, last accessed on 23 January 2012.

http://reg666.blogspot.com, last accessed on 23 January 2012.

http://usk-lootus-armastus.blogspot.com, last accessed on 23 January 2012.

http://virgokruve.wordpress.com, last accessed on 23 January 2012.

http://voyag.blogspot.com, last accessed on 23 January 2012. 